\title{
PENINGKATAN EKONOMI KELUARGA MELALUI PEMBERDAYAAN MASYARAKAT DENGAN MEMBUAT SANDAL HIAS
}

\author{
Gunartin*, Denok Sunarsi, Syafaatul Hidayati \\ Dosen Pendidikan Ekonomi FKIP Universitas Pamulang \\ Email* : atin_gunartin@yahoo.com
}

\begin{abstract}
ABSTRAK
Tujuan dari pengabdian kepada masyarakat ini, selain sebagai pemenuhan kewajiban melakukan Tridharma Perguruan Tinggi juga sebagai wujud kepedulian akademisi kepada warga masyarakat sekitar untuk membangun ekonomi keluarga sebagai fundamental membangun perekonomian bangsa.

Pendekatan metodologi yang digunakan pada pengabdian kepada masyarakat ini dengan pendekatan penyuluhan dan pelatihan membuat sandal hias yang mempunyai nilai ekonomis, yang nantinya dapat dijual sebagai sumber penghasilan keluarga.

Hasil dari kegiatan pengabdian kepada masyarakat ini, masyarakat mendapatkan wawasan cara membuat sandal hias dengan memanfaatkan kain perca melalui simulasi pembuatan sandal hias dengan harapan dapat diteruskan dirumah masing-masing dan terus dikembangkan dengan sentuhan kreatif dan inovatif.
\end{abstract}

\section{Kata kunci: Ekonomi Keluarga, Pemberdayaan Masyarakat}

\section{PENDAHULUAN}

Sebagai seorang akademisi ditingkat Perguruan Tinggi, mempunyai kewajiban melaksanakan Tridharma Perguruan Tinggi, yaitu: pengajaran, penelitian dan pengabdiaan kepada masyarakat. Maka dari itu sudah seyogyanya dosen melakukan pengabdian kepada masyakarat sebagai implementasi dari pengembangan penelitian dan pengajaran. Artinya, dosen melakukan riset dengan harapan dapat diimplementasikan pada masyarakat dalam bentuk pengabdian kepada masyarakat.

Pengabdian kepada masyarakat dilakukan oleh dosen dan mahasiswa sebagai wujud kepedulian kepada masyarakat sekitar dengan didasarkan pada motivasi yang membangun, jiwa berwirausaha yang kreatif dan kompeten sehingga tujuan pembelajaran dapat dicapai. Pengabdian kepada masyarakat tidak sekedar menggugurkan kewajiban sebagai dosen ataupun mahasiswa, melainkan sebagai 
bentuk mengimplementasikan ilmu pengetahuan hasil proses pembelajaran kepada masyarakat luas untuk dikembangkan dan diproyeksikan sehingga memberikan manfaat bagi mahasiswa, dosen dan masyarakat.

Masa era globalisasi seperti sekarang ini, menuntut kuliatas sumberdaya manusia dengan berbagai potensi agar siap menghadapi tingkat persaingan yang semakin kompetitif. Artinya, untuk mencari penghasilan sebagai karyawan semakin sulit, sementara kebutuhan hidup semakin meningkat. Untuk itu penting bagi khususnya ibu-ibu rumah tangga untuk dapat berkreasi dan berkarya menghasilkan barang atau jasa yang bisa dijadikan sumber penghasilan untuk membantu menopang ekonomi keluarga. Ekonomi keluarga bisa dibangun di rumah-rumah sebagai wadah untuk berkreasi menambah nilai suatu barang dengan memanfaatkan barang-barang yang tidak lagi mempunyai nilai secara ekonomi menjadi barang yang mempunyai nilai ekonomi dan nilai guna.

Babakan merupakan nama salah satu desa yang berada di dalam wilayah Kecamatan Setu Kota Tangerang Selatan. Ditinjau dari letaknya Desa Babakan yang strategis dan padat penduduk menunjukkan potensi pasar yang cukup besar. Namun demikian belum tampak menggeliatnya perekonomian wilayah setempat. Dari hasil surve ternyata sebagian besar memang berprofesi sebagai ibu rumah tangga murni. Melhat kondisi yang demikian penulis tertarik melakukan penyuluhan dan simulasi pembuatan sandal hias untuk pemberdayaan masyarakat setempat guna meningkatkan perekonomian keluarga melalui kemasan pengabdian kepada masyarakat dengan tema "Peningkatan Ekonomi Keluarga Melalui Pemberdayaan Masyarakat Dengan Sandal Hias"

\section{FOKUS PENGABDIAN}

Berdasarkan latar belakang di atas, penulis ingin memfokuskan pengabdian kepada masyarakat ini pada peningkatan ekonomi keluarga melalui pemberdayaan masyarakat dengan membuat sandal hias yang dilakukan oleh dosen dan mahasiswa Universitas Pamulang.

\section{TUJUAN}

Adapun tujuan dari kegiatan pengabdian kepada masyarakat ini adalah untuk menggerakkan masyarakat agar melek mata bahwa sekarang ini harus berkarya menghasilkan barang dan jasa untuk memberi nilai tambah secara ekonomis pada barang bekas atau sudah tidak digunakan sehingga memberi nilai guna dan mampu meningkatkan perekonomian keluarga. Artinya, dengan kegiatan pengabdian kepada masyarakat ini diharapkan mampu memberi angin segar bagi ibu-ibu rumah tangga untuk mengembangkan kreatifitasnya menghasilkan barang 
atau jasa yang lebih bermanfaat dan bernilai ekonomis sehingga mampu menjadi sumber penghasilan dan menopang ekonomi keluarga.

\section{KEGIATAN}

Kegiatan pengabdian kepada masyarakt ini difokuskan kepada ibu-ibu rumah tangga khususnya bagi yang belum berpenghasilan di wilayah Desa Babakan Kecamatan Setu Tangerang Selatan.

Adapun pelaksanaan kegiatan pengabdian kepada masyarakat iini sebagai berikut:

Hari

: Jumat - Minggu

Tanggal

: 15 - 18 September 2017

Waktu

: pukul 13.00 - 15.00 WIB

Tempat

: Aula Kelurahan Babakan Kecamatan Setu

Jumlah Peserta : 20 orang

Acara

: Penyuluhan dan simulasi pembuatan sandal hias

\section{APLIKASI}

\section{A. Ekonomi Keluaga}

Ekonomi keluarga merupakan salah satu unit kajian ekonomi pada unit paling kecil dari unit ekonomi yang memiliki peran sebagai upaya membebaskan manusia pada tingkat kemiskinan. Dalam masyarakat, ekonomi keluarga diklasifikasikan dalam tiga lapisan ekonomi, yaitu:1) ekonomi mampu; 2) ekonomi sedang; dan 3) ekonomi keluarga tidak mampu. Ekonomi merupakan faktor yang menentukan perilaku seseorang dalam masyarakat.

Ekonomi keluarga juga sangat menentukan tingkat kemampuan pemenuhan kebutuhan anggota keluaga, secara berkelanjutan yang mencerminkan peningkatan ekonomi keluarga. Untuk sampai pada posisi aman dalam ekonomi keluarga perlu upaya untuk terus meningkatkan pendapatan dan mampu memanfaatkan seefisien mungkin dalam pemenuhan kebutuhan sehingga masih ada kelebihan yang dapat ditabung atau diinvestasikan secara berkelanjutan. Dalam kurun waktu yang lama apabila diakumulasikan maka akan dapat terkumpul dalam jumlah yang besar yang merupakan kekayaan pribadi.

Peningkatan ekonomi keluarga akan dapat diwujudkan apabila, 1) anggota keluarga memiliki kesadaran yang mendorong pencapaian peningkatan ekonomi; 2) semua anggota keluarga memiliki perilaku jujur, berkomitmen, terbuka, disiplin, bertanggung jawab serta mampu bekerjasama untuk satu tujuan yaitu meningkatkan perekonomian keluarga; 3) memberdayakan kemampuan atau potensi yang dimiliki keluarga dengan harapan dapan meningkatkan 
pendapatan keluarga; 4) semua anggota keluarga mampu memanfaatkan alokasi sumber ekonomi keluarga berdasarkan kebutuhan bukan keinginan; dan 5) semua anggota keluarga berkomitmen melakukan pengendalian perekonomian kelurga sebaik-baiknya.

\section{B. Pemberdayaan Masyarakat}

Pemberdayaan pada prinsipnya sebuah proses dalam suatu kegiatan untuk menghasilkan suatu yang bermanfaat. Dalam hal ini, pemberdayaan masyarakat lebih diarahkan untuk peningkatan ekonomi keluarga. Pemberdayaan masyarakat merupakan upaya untuk memberikan daya (empowerment) kepada masyarakat.

Atau dapat dijelaskan bahwa pemberdayaan masyarakat proses peningkatan kemampuan individu yang menyatu dengan masyarakat yang bersangkutan sehingga dapat ditemukan alternatif-alternatif baru dalam pembangunan masyarakat (Mardikanto, 2014). Indikator pembangunan masyarakat yaitu apabila masyarakat dinilai sebagai subyek atau motor penggerak dan bukan sebagai penerima manfaat.

Pemberdayaan masyarakat juga dapat diartikan sebagai suatu proses pembangunan masyarakat yang dimulai dengan proses kegiatan sosial untuk memperbaiki kondisi perekonomina diri. Dengan kata lain, pemberdayaan masyarakat ini hanya dapat terlaksanan apabila partisipasi masyarakat yang bersangkutan terbangun.

Berdasarkan uraian di atas dapat di simpulkan bahwa pemberdayaan merupakan proses pembangunan dimana masyarakat berinisiatif untuk memperbaiki situasi dan kondisi diri.

\section{Profil Lokasi PkM}

Pilihan lokasi pengabdian kepada masyarakat yaitu Desa Babakan Kecamatan Setu Tangerang Selatan dengan pertimbangan bahwa daerah tersebut memiliki potensi pasar yang cukup besar. Dengan pangsa pasar yang besar akan memberikan peluang yang besar pula untuk melakukan kegiatan ekonomi yang dapat mendatangkan manfaat bagi masyarakat terutama untuk pemberdayaan guna meningkatkan ekonomi. Selain memiliki potensi pangsa pasar yang cukup luas Desa Babakan juga letaknya strategis yaitu dekat dengan lokasi pasar dan dunia pendidikan, tentu hal ini sudah menunjukan bahwanya lokasi Desa babakan memiliki potensi untuk dikembangkan diberdayakan untuk meningkatkan kesejahteraan ekonomi masyarakat. 
Desa Babakan merupakan salah satu desa yang berada di dalam wilayah Kecamatan Setu yang sangat strategis dan berpotensi yang luas wilayahnya mencapai $8.980 \mathrm{~m}^{2}$ dengan jumlah penduduk 179 orang usia dewasa dengan rincian disajikan pada Tabel 1.

Tabel 1. Rincian Status Penduduk Desa Babakan Tahun 2016

\begin{tabular}{|c|l|r|}
\hline No & \multicolumn{1}{|c|}{ Status Penduduk } & Jumlah (orang) \\
\hline 1 & Buruh lepas & 55 \\
\hline 2 & Pedagang & 42 \\
\hline 3 & Pembantu rumah tangga & 36 \\
\hline 4 & Karyawan swasta & 24 \\
\hline 5 & Pelajar & 9 \\
\hline 6 & Belum bekerja & 7 \\
\hline 7 & Petani & 3 \\
\hline 8 & Peternak & 1 \\
\hline 9 & Pensiunan & 1 \\
\hline 10 & Pegawai negeri sipil & 1 \\
\hline
\end{tabular}

Sumber: Dokumen Kantor Desa Babakan

Berdasarkan tabel 1 tersebut dapat ditunjukkan bahwa buruh lepas jumlahnya paling banyak yaitu 55 orang dan diikuti sebagai pengurus rumah tangga berjumlah 36 orang, artinya kestabilan ekonomi belum dapat dikatakan mapan karena buruh lepas merupakan pekerjaan yang tidak tetap. Dengan letak strategis yang dimiliki Desa Babakan sebenarnya dapat dikembangkan ke arah pemberdayaan masyarakat agar terjadi peningkatan perekonomian.

Letak Kecamatan Setu yang berbatasan dengan Kecamatan Serpong dan Pamulang akan membantu akses berkembangnya wilayah Kecamatan Setu. Apalagi di Pamulang mempunyai aset yang menjadi ikon Kecamatan Pamulang yaitu Universitas Pamulang hal ini memberikan peluang yang sangat besar bagi Desa Babakan untuk mengembangkan ekonomi daerahnya. Misal, usaha makanan, sewa tempat tinggal (kost-kost an), serta kebutuhan pokok lainnya seperti pakaiaan, sepatu, tas, sandal atau piranti yang lainnya. Begitu juga dengan Kecamatan Serpong yang memberikan aksses ke Tangerang Kota sangat berpotensi untuk pemberdayaan dan pengembangan kegiatan ekonomi. Kecamatan Setu berbatasan dengan Kecamatan Serpong dan Pamulang dapat ditinjukkan paga gambar 1. 


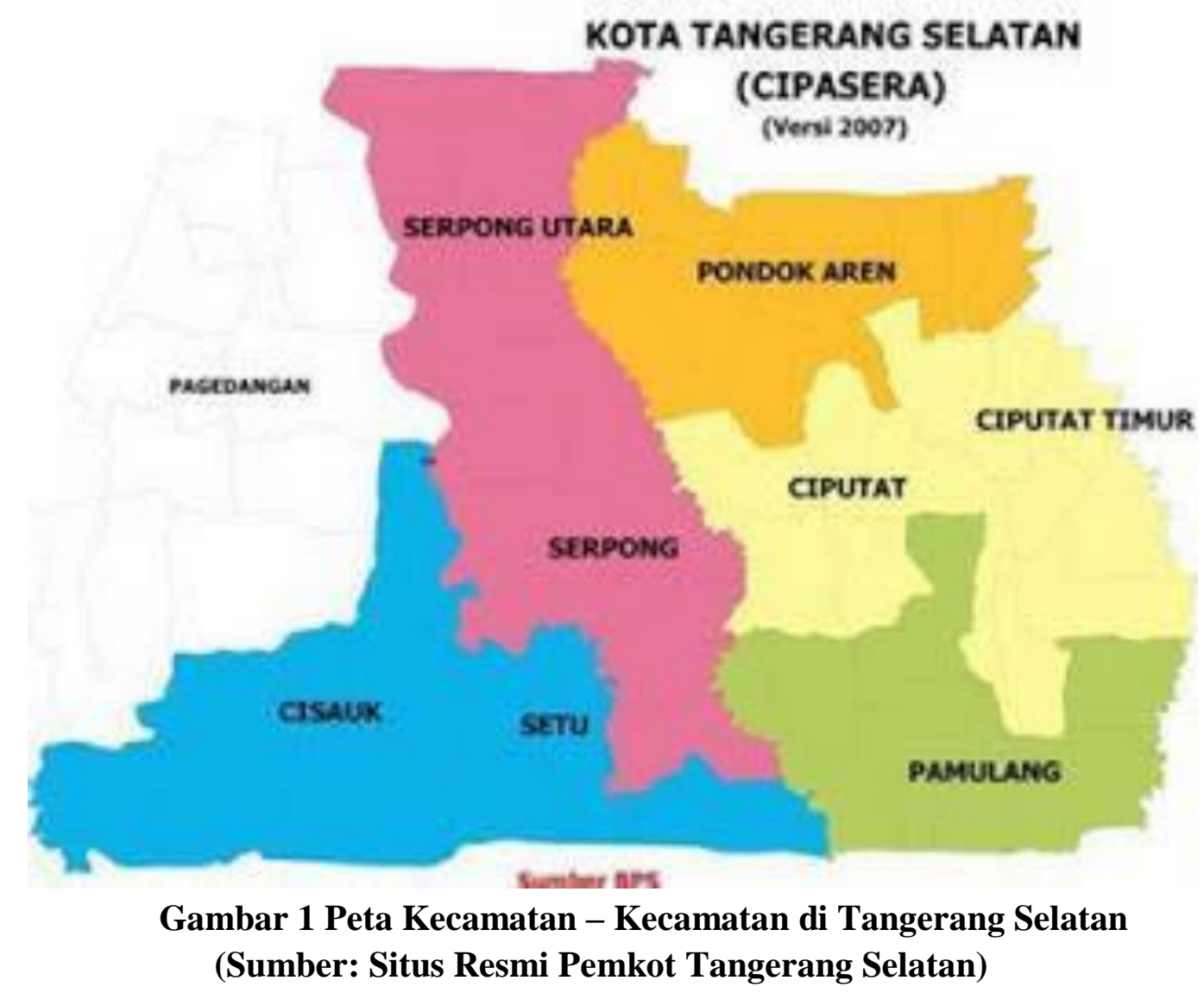

Dibalik letaknya yang strategis dan berpotensi untuk berkembang, masyarakat Desa Babakan belum melakukan optimalisasi pada sumber daya ekonomi yang dimiliki, sehingga mayoritas ibu-ibu Desa Babakan masih sebagai ibu rumah tangga dan sebagai pembantu rumah tangga. Berdasarkan data yang tersajikan pada tabel 1 yang menjadi pembantu rumah tangga mencapai $20 \%$ dari 179 yaitu 36 orang. Melihat karakter masyarakat Desa Babakan memang perlu motivasi, arahan, bimbingan, serta pendampingan pada masyarakat agar menjadi masyarakat yang mandiri melalui penyuluhan, pelatihan dan pembinaan untuk menumbuhkembangkan kreativitas warga masyarakat, minimal dapat membuka lapangan pekerjaan untuk dirinya sendiri, keluarganya, dan akan lebih baik lagi kalau bisa membuka lapangan pekerjaan untuk masyarakat luas.

\section{Pembuatan Sandal Hias}

Sebagai seorang akademisi yang menjadi bagian dari civitas akademika, mempunyai kewajiaban melaksanakan tridharma pergurunan tinggi agar dapat menghasilkan output yang prosesional, kreatif dan inovatif serta mejunjung 
tinggi visi dan misi Universitas Pamulang, khususnya program studi Pendidikan Ekonomi yang mempunyai visi menjadi program studi yang unggul dan kompetitif di tingkat nasional dilandasi nilai humanis dan religius, dimana salah satu misinya adalah menyelenggarakan pengabdian kepada masyarakat melalui penerapan ilmu dan teknologi dalam bidang pendidikan ekonomi. Berdasarkan hal tersebut di atas, perlu bagi civitas akademika melakukan pengabdian kepada masyarakat, yang kali ini memilih lokasi di Desa Babakan Kecamatan Setu Tangerang selatan dengan topik pemberdayaan masyarakat dengan pembuatan sandal hias untuk meningkatkan ekonomi keluarga.

Pengabdian kepada masyarakat yang berlokasi di Desa Babakan ini dikemas dalam bentuk pemberdayaan ekonomi masyarakat dengan pelatihan pembuatan sandal hias. Topik ini dipilih karena kegiatan pelatihan pembuatan sandal hias dapat meningkatkan kreatifitas warga dengan memanfaatkan limbah perca. Kegiatan ini diharapkan dapat menumbuhkan kesadaran masyarakat bahwa limbah perca juga dapat mempunyai nilai manfaat dan nilai ekonomis dengan catatan perlu sentuhan tanggan-tangan kreatif untuk dapat mengubah kain perca menjadi barang yang bernillai manfaat dan bernilai ekonomis. Dan yang lebih penting lagi dapat membuka lapangan pekerjaan bagi diri sendiri, keluarga serta masyarakat ataupun membuka peluang berwirausaha. Pemanfaatan limbah perca diharapkan juga dapat membentuk lingkungan yang bersih karena kain sisa jahitan (kain perca) dapat dimanfaatkan untuk barang yang lebih berguna.

Kegiatan pembuatan sandal hias membutuhkan bahan sepasang sandal jepit, kain perca, lem, pita dan aksesoris lain untuk mempercantik tampilan sandal setelah dibalut dengan kain perca. Kegiatan pengabdian kepada masyarakat ini dikhususkan untuk ibu-ibu yang belum mempunyai penghasilan tetap. Dengan mampu membuat sandal hias yang kreatif dan inovatif tentu akan membuka peluang baru untuk menjadi pengusaha. Pembuatan sandal hias ini hanya butuh kreativitas untuk mengkombinasi kain perca sebagai pelapis luar sandal sehingga akan dihasilkan sandal hias yang unik, dengan harapan dapat diproduksi dalam jumlah yang besar dan dapat dipasarkan sebagai sumber penghasilan yang tetap. Proses kegiatan pengabdian kepada masyarakat dengan topik peningkatan ekonomi keluarga melalui pembuatan sandal hias ini dapat ditunjukkan pada gambar 2 . 


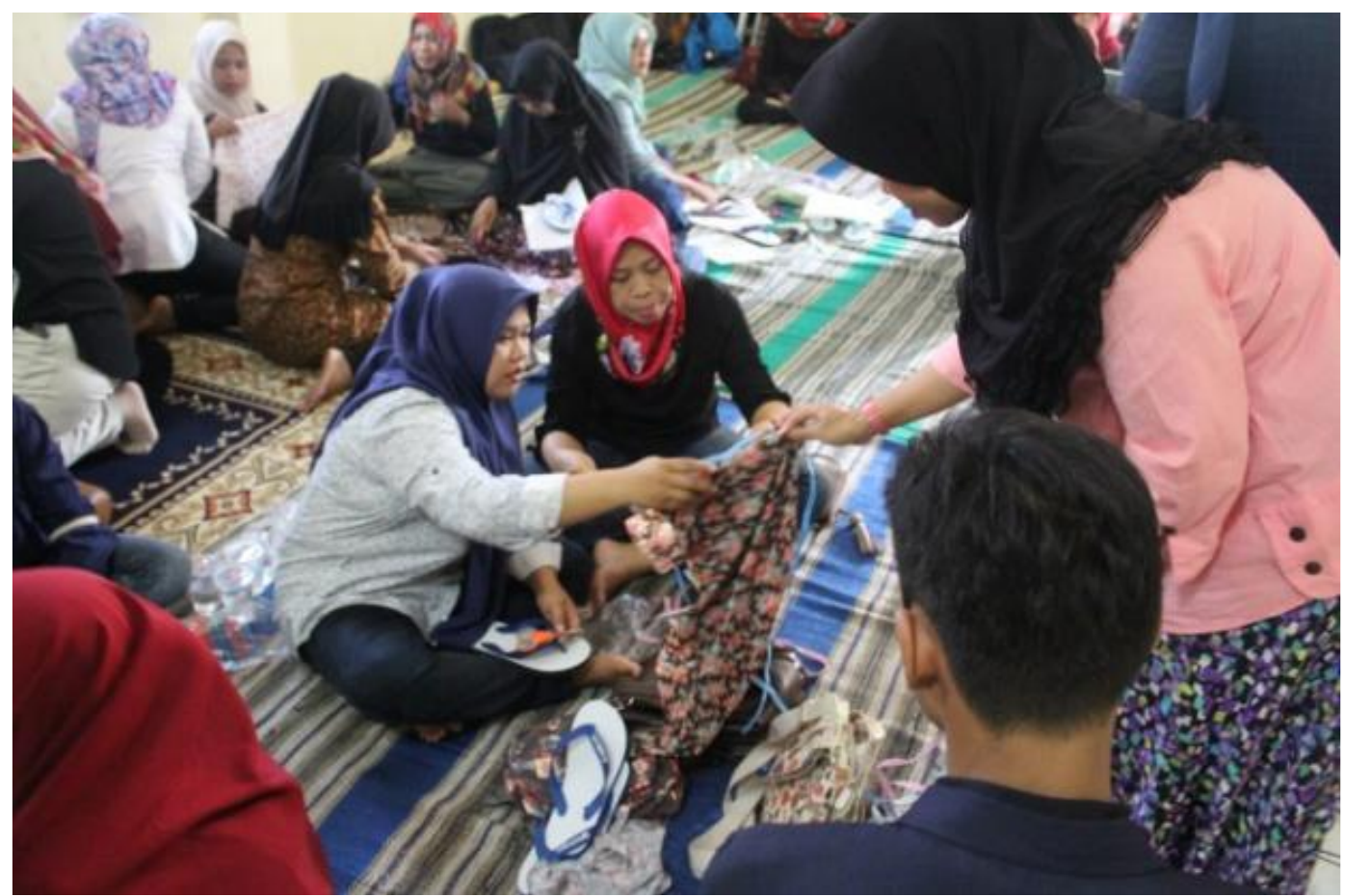

Gambar 2. Proses Pelatihan Pembuatan Sandal (sumber dokumen kegiatan)

Pelatihan yang bertajuk membangun kreativitas dan wawasan pada masyarakat ini sengaja dipersembahkan untuk pemberdayaan masyarakat guna meningkatkan perekonomian keluarga yang secara otomatis akan meningkatkan perekonomian masyarakat. Kegiatan yang dikemas dalam bentuk pelatihan ini diikuti oleh 30 orang ibu-ibu warga Desa Babakan, 10 dosen, serta 10 mahasiswa dari program studi pendidikan ekonomi.

\section{E. Penutup}

Kegiatan pengabdian kepada masyarakat ini memang bukan satu-satunya jalan keluar untuk peningkatan ekonomi keluarga, tetapi merupakan alternatif yang dapat dikembangkan dengan memanfaatkan limbah kain perca yang semestinya dibuang. Dengan ditangani secara kreatif dan inovatif melalui pemberdayaan masyarakat melalui pembuatan sandal hias, kain perca yang fungsinya sebagai bahan penolong tidak saja mempercantik tampilan sandal japit tetapi juga dapat menambah penghasilan tukang jahit atau yang memfaatkan kain perca tersebut.

Saran yang dapat penulis sampaikan kepada masyarakat Desa Babakan khususnya dan masyarakat pada umumnya, kreativitas dapat merubah nilai suatu barang dari yang kurang bernilai menjadi bernilai guna dan bernilai ekonomis, 
maka dari itu manfaatkan sumberdaya yang ada untuk terus dikembangkan dan diberdayakan agar mendatangkan manfaat bagi diri sendir ataupun orang lain.

\section{DAFTAR PUSTAKA}

Mardikanto Totok, 2014.Corporate Social Responsibility, Tanggung jawab Sosial Korporasi, Alfabeta Bandung

https://id.wikipedia.org/wiki/ekonomi keluarga, diakses Senin, 25 November 2018

https://id.wikipedia.org/wiki/pemberdayaan_masyarakat diakses Senin 25

November 2018

https://id.wikipedia.org/wiki/kewirausahaan, diakses Selasa, 26 November 2018 https://id.wikipedia.org/wiki/daftar_kecamatan_dan_kelurahan_di_Tangerang

Selatan, diakses Jumat, 30 November 2018

\section{DOKUMENTASI FOTO KEGIATAN}

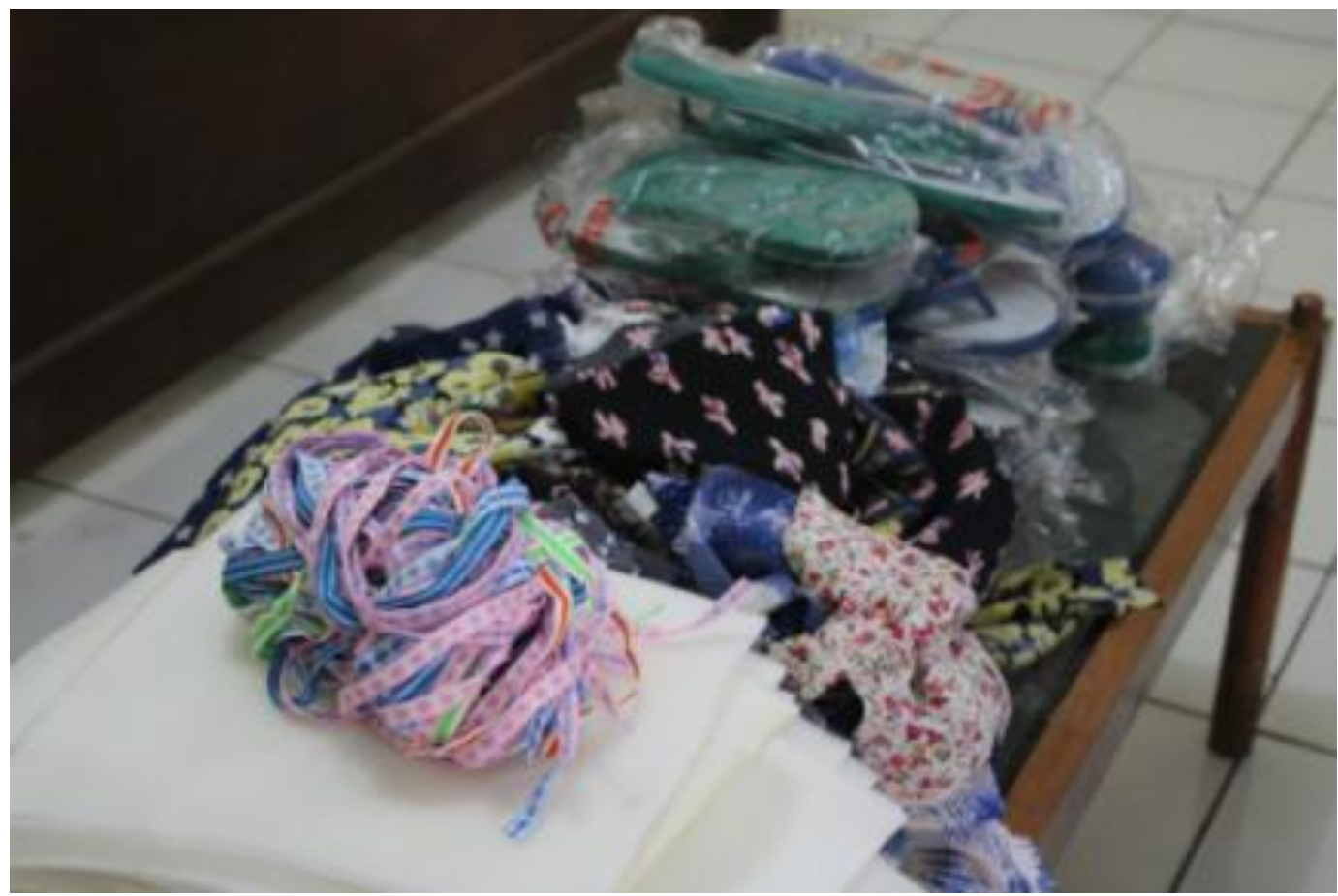

Alat dan bahan yang dipaka untuk membuat sandal hias 


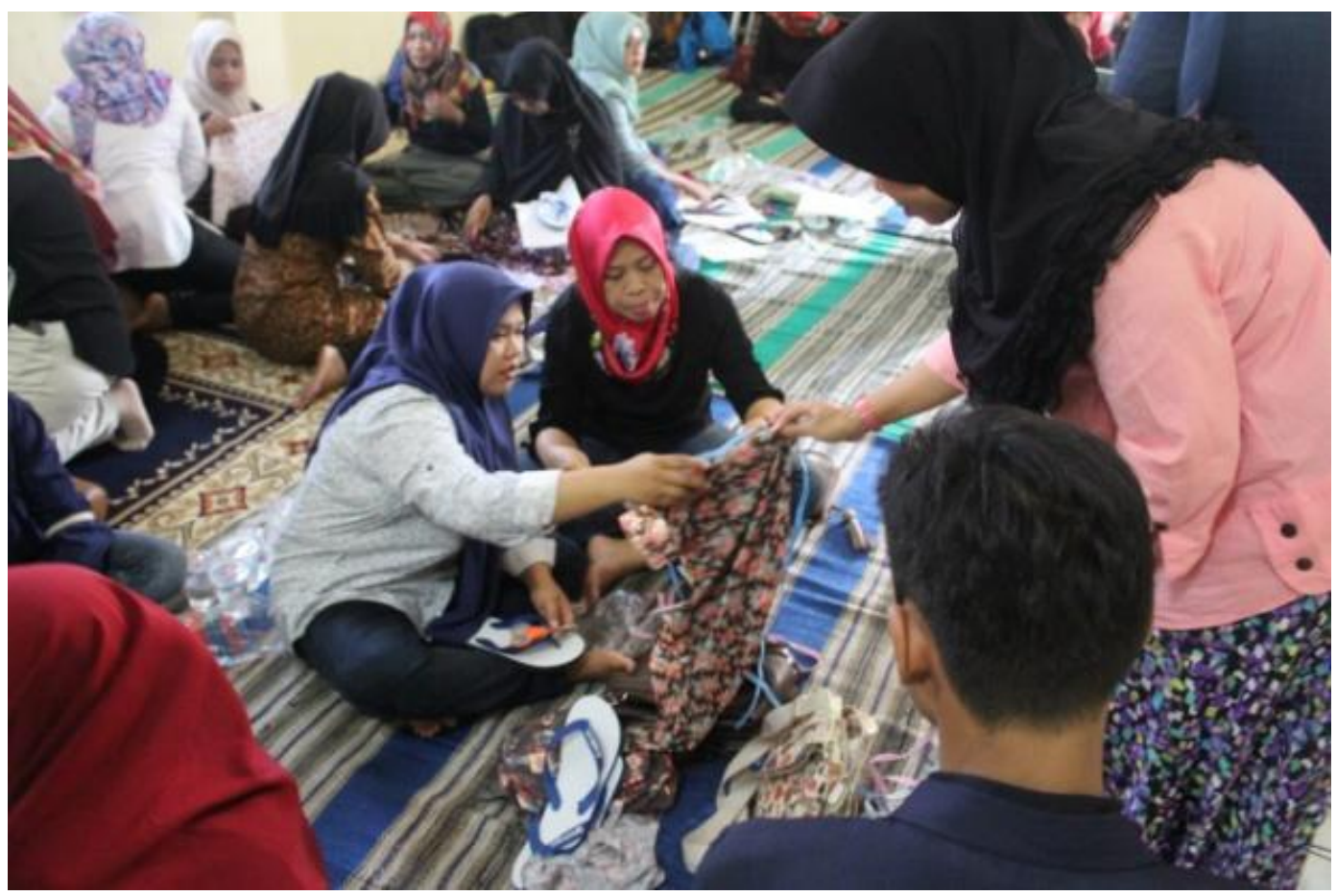

Proses Pembuatan Sandal Hias

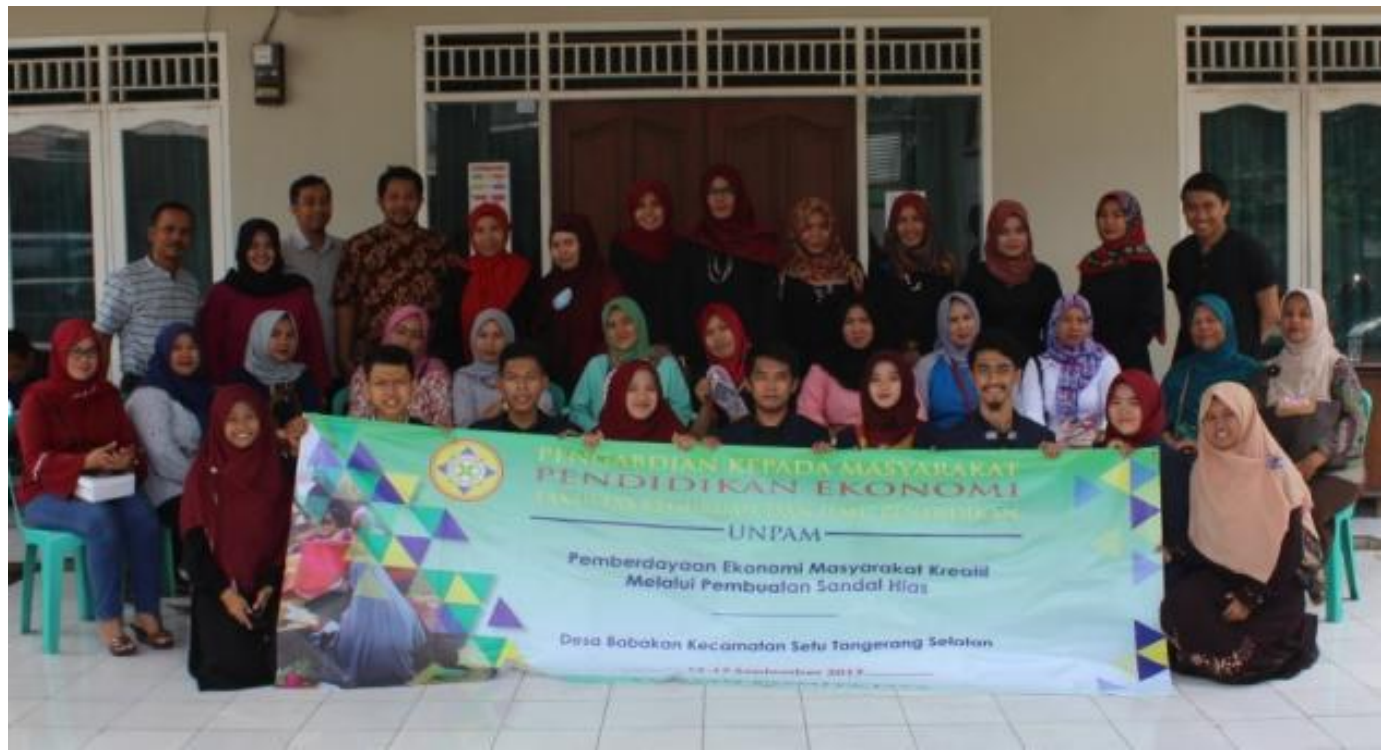

Tim Pelaksana Pengabdian Kepada Masyarakat 